\title{
Editorial
}

\section{Herbal drugs as immune-modulators in case of COVID-19}

\author{
Phalke Pallavi $\mathbf{L}^{1, *}$, Thitame Sonal $\mathbf{A}^{\mathbf{1}}$, Nawale Akshada $\mathbf{S}^{\mathbf{1}}$ \\ ${ }^{1}$ Dept. of Pharmacy, ARIMET's Matoshri Radha college of D. Pharmacy Anandgad, Ahmednagar, Maharashtra, India
}

A R T I C L E I N F O

Article history:

Received 19-06-2021

Accepted 17-09-2021

Available online 28-10-2021
This is an Open Access (OA) journal, and articles are distributed under the terms of the Creative Commons Attribution-NonCommercial-ShareAlike 4.0 License, which allows others to remix, tweak, and build upon the work non-commercially, as long as appropriate credit is given and the new creations are licensed under the identical terms.

For reprints contact: reprint@ipinnovative.com
Current scenario tells us that the world is seviourly affected by covid-19 pandemic; Dec 2019 corona virus came into existence and changes our life completely. Prime moto is to take the safety precautions like wearing masks, using sanitizers, staying indoors and maintaining social distancing and strengthen the immunity. ${ }^{1}$ This Disease is communicated by a Novel corona virus which is also known as acute respiratory syndrome corona virus 2 i.e. SARSCoV2. This virus belong to seventh coronaviridea family which is responsible for infecting the human beings. ${ }^{2,3}$ The major reason fast spread of this disease is due to close contact with infected person through droplets eighter from sneezing or coughing. ${ }^{4}$ this disease id having variety of symptoms and the symptoms are mild to severe. Majority of patient shows the fever followed by cough, myalgia and fatique. Sputum production and headache is also seen. Sometimes virus directly attacks the alveolar epithelial cell which may lead to respiratory failure which may be fetal to patient. $^{5}$

This small virus affects the drug to that large extend because of lack of drugs medicines and vaccines as well so to beat this condition one can follow all the rules and regulations regarding covid-19 and boost immunity. ${ }^{1}$

Ayurveda and some traditional Chinese medicines from vedic period 1600-500 BCE, giving world the potential medicines to boost the immunity and cure against illness caused by micro-organism. ${ }^{6}$ Drugs from ayurveda

\footnotetext{
* Corresponding author.

E-mail address: falkepallavi@gmail.com (Phalke Pallavi L).
}

having wide range of effectiveness against various microorganisms without showing any side effect. By taking herbal drugs or medicines which are having active chemical constituent which may be having therapeutic effect like antiinflammatory, antiviral, etc. ${ }^{7}$ Curcuma longa widely used as ayurvedic drug because of its effects like anti-oxidants, anti-inflammatory, anti mutagenic, anticancer, antimicrobial effects. $^{8,9}$

The drugs containing active constituents like flavanoids, proanthocyanidins, saponins, monoterpenoids, triterpenoids, glucosides, sesquiterpenes, and alkaloids shows activity against viral infections. ${ }^{10}$ Ashvagandha, giloe, tulasi, cardamom, cinnamon, cinchona, turmeric, amla, black pepper, fennel, garlic are some common examples of drugs used from the ancient times to cure multiple diseases. In india generally all this herbs are used in the day to day activities and some of the herbs are integral part of the Indian kitchen. Almost all the drugs having immunomodulatory activities. All this drugs are very common Indian day to day life. Every Indian no matter what religion, financial conditions, Geographical state, community they belong one of the above mentioned drug is used daily. All the drugs potentially proven for their immune modulatory, anti-oxidant and anti inflammatory properties. Because of that only the death rate in india is lower than others. ${ }^{11}$

Glycyrhiza Glabra roots are used in treatment of bronchitis and gastritis from ancient times. It is also having anti-oxidant and anti-inflammatory property. 
Citrus Limon (Lemon)-Lemon is rich in vitamin $\mathrm{C}$ and it is also used to relieve cough and used as expectorant in bronchitis. It is also used as anti-inflammatory for sore throat. ${ }^{12}$

Gingiber Officinalis (Ginger)-Many preclinical studies reports analgesics, expectorant, anti-pyretic and antiinflammatory effect. It is also effective in common cold and cough, asthma. ${ }^{13,14}$

The dictoction of ginger, colve and piper nigrum provides humeral and cell mediated response to healthy as well as covid-19 infected person. It also reduces the nasal congestion. The drug like Tulsi is present in every home garden also having wide range of effects like anti-microbial aromatic etc. ${ }^{15-17}$

\section{References}

1. Khanna K, Kohli S, Kaur R, Bhardwaj A, Bhardwaj V, Ohri $\mathrm{P}$, et al. Herbal immune-boosters: Substantial warriors of pandemic Covid-19 battle. Phytomedicine. 2021;85:153361. do1:10.1016/].phymed.2020.153361.

2. Cheepsattayakorn R, Cheepsattayakorn. Proximal origin and phylogenetic analysis of COVID-19 (2019-nCoV or SARS-CoV-2). EC Microbiology. 2020;19:9-12.

3. World Health Organization, Coronavirus Disease 2019, World Health Organization, Geneva, Switzerland, 2020, https:// www.who.int/emer gencies/diseases/novel-coronavirus-2019;

4. Adhikari SP, Meng S, Wu Y. Epidemiology, causes, clinical manifestation and diagnosis, prevention and control of coronavirus disease (COVID-19) during the early outbreak period: a scoping review. Infect Dis Poverty. 2020;9(29):1-12.

5. Huang C, Wang Y, Li X. Clinical features of patients infected with 2019 novel coronavirus in Wuhan. Lancet. 2020;395(10223):497-506.

6. Chattopadhyay D, Ojha D, Mondal S, Goswami D. Validation of antiviral potential of herbal ethnomedicine. In: Muherjee PK, editor. Evidence-Based Validation of Herbal Medicine. Elsevier, Public Health Care Collection; 2015. p. 175-200

7. Sharma M, Anderson SA, Schoop R, Hudson JB. Induction of multiple pro-inflammatory cytokines by respiratory viruses and reversal by standardized Echinacea, a potent antiviral herbal extract. Antivir Res. 2009;83(2):165-70.

8. Kocaadam B, Şanlier N. Curcumin, an active component of turmeric (Curcuma longa), and its effects on health. Crit Rev Food Sci Nutr.
2017;57(13):2889-95.

9. Zhang L, Liu Y. Potential interventions for novel coronavirus in China: a systematic review. J Med Virol. 2020;92(5):479-90.

10. Muchtaridi M, Sugijanto M, Gazzali AM, Wahab HA. Antineuraminidase bioactives from Manggis Hutan (Garcinia celebicaL.) leaves: Partial purification and molecular characterization. Molecules. 2020;25(4):821. 101:103300/molecules 250408211.

11. Ahmad S, Zahiruddin S, Parveen B, Basist P, Parveen A, Gaurav, et al. Indian Medicinal Plants and Formulations and Their Potential Against COVID-19-Preclinical and Clinical Research. Front Pharmacol. 2021;11:578970. doi:10.3389/fphar.2020.578970

12. Papp N, Bartha S, Boris G, Balogh L. Traditional Uses of Medicinal Plants for Respiratory Diseases in Transylvania. Nat Prod Comm. 2011;6(10):1459-60.

13. COLOMBIA (2008). Vademecum Colombiano de Plantas Medicinales (Bogotá:Ministerio de la Protecion Social /Imprenta Nacional Colombiana).; 2008.

14. WHO (1999). Monographs on selected medicinal plants (Geneva: World Health Organization);

15. Brasil (2011). Formulário de Fitoterápicos da Farmacopeia Brasileira (Brasilia: Agência Nacional de Vigilância Sanitária).

16. Carrasco FR, Schmidt G, Romero AL, Sartoretto JL, CaparrozAssef SM, Bersani-Amado CA, et al. Immunomodulatory activity of Zingiber officinale Roscoe, Salvia officinalis L. and Syzygium aromaticum L. essential oils: evidence for humor-and cell-mediated responses. J Pharma Pharmacol. 2009;61(7):961-7.

17. Kim SH, Lee YC. Piperine inhibits eosinophil infiltration and airway hyperresponsiveness by suppressing $\mathrm{T}$ cell activity and Th2 cytokine production in the ovalbumin-induced asthma model. $J$ Pharma Pharmacol. 2009;61(3):353-9.

\section{Author biography}

Phalke Pallavi L, Principal

Thitame Sonal A, Lecturer

Nawale Akshada S, Lecturer

Cite this article: Phalke Pallavi L, Thitame Sonal A,

Nawale Akshada S. Herbal drugs as immune-modulators in case of COVID-19. IP Int J Comprehensive Adv Pharmacol 2021;6(3):94-95. 